\title{
Self-reported symptoms of uninvestigated dypepsia among University staff in Ilorin, Nigeria
}

\author{
*Ogunmodede JA. ${ }^{1}$, Bojuwoye MO. ${ }^{1}$, Olokoba AB. ${ }^{1}$, Bolarinwa OA. ${ }^{2}$, Kolo PM. ${ }^{1}$
}

\begin{abstract}
Objectives: Dyspepsia is a common gastrointestinal (GI) symptom which impacts negatively on quality of life, workplace efficiency and overall productivity. Many studies on dyspepsia in our environment are hospital based, but being a complaint frequently treated first by self-medication before presentation to the hospital, such studies may underestimate its prevalence. The objective of the study was to determine the prevalence of the dyspepsia and its associated factors among administrative staff of the College of Health Sciences, University of Ilorin, Nigeria.
\end{abstract}

Methods: This was a cross-sectional study. Pretested structured, close-ended, interviewer-administered questionnaires were administered to 53 administrative staff selected across the different units by stratified random sampling. The questionnaire obtained information about subject's experiences of dyspeptic symptoms and presence of associated factors such as family history, non-steroidal anti-inflammatory drugs (NSAIDS), tobacco and alcohol use, and presence of diabetes mellitus (DM).

Results: The prevalence of uninvestigated dyspepsia among the respondents was $37.5 \%$. Age was significantly predictive of the occurrence of dyspepsia among the subjects Odds Ratio- 1.46 , 95\% Confidence Interval (1.042-2.045) $\mathrm{P}=0.03$. Use of NSAIDS, presence of DM, family history and tobacco use were not predictive of occurrence of dyspepsia.

Conclusion: The prevalence of dyspepsia is high among respondents in the study.

Keywords: Dyspepsia, prevalence, university, Nigeria

*Correspondence Author: Dr Ogunmodede JA, Email: ayodeleogunmodede@yahoo.com

'Department of Medicine, Faculty of Clinical Sciences, University of Ilorin, Nigeria

${ }^{2}$ Department of Epidemiology and Community Health, Faculty of Clinical Sciences, University of Ilorin, Nigeria

Research Journal of Health Sciences subscribed to terms and conditions of Open Access publication. Articles are distributed under the terms of Creative Commons Licence (CC BY-NC-ND 4.0). (http://creativecommons.org/licences/by-nc-nd/4.0).

http://dx.doi.org/10.4314/rejhs.v4i4.5 


\title{
Symptômes autodéclarés de la dypepsie non recherchée chez le personnel de l'Université à Ilorin, au Nigeria
}

\author{
Ogunmodede JA. ${ }^{1}$, Bojuwoye MO. ${ }^{1}$, Olokoba AB. ${ }^{1}$, Bolarinwa OA. ${ }^{2}$, Kolo PM. ${ }^{1}$
}

\begin{abstract}
Resume
Objectifs: La dyspepsie est un symptôme gastro-intestinal (GI) commun qui a un impact négatif sur la qualité de vie, l'efficacité au travail et la productivité globale. De nombreuses études sur la dyspepsie dans notre environnement sont basées à l'hôpital, mais étant une plainte fréquemment traitée en premier lieu par l'automédication avant la présentation à l'hôpital, de telles études peuvent sous-estimer sa prévalence. L'objectif de l'étude était de déterminer la prévalence de la dyspepsie et ses facteurs associés parmi le personnel administratif du Collège des sciences de la santé de l'Université d'Ilorin au Nigeria.
\end{abstract}

Méthodes: Il s'agissait d'une étude transversale. Des questionnaires structurés, étroits et administrés par intervieweur ont été administrés à 53 membres du personnel administratif sélectionnés dans les différentes unités par échantillonnage aléatoire stratifié. Le questionnaire a permis d'obtenir des informations sur les symptômes dyspeptiques et la présence de facteurs associés tels que les antécédents familiaux, les anti-inflammatoires non stéroïdiens (AINS), la consommation de tabac et d'alcool et la présence de diabète sucré.

Résultats: La prévalence de la dyspepsie non étudiée chez les répondants était de 37,5\%. L'âge était significativement prédictif de l'apparition de la dyspepsie chez les sujets Ratio des cotes - 1,46, 95\% Intervalle de confiance 1,042-2,045, P =0,03. L'utilisation d'AINS, la présence de DM, les antécédents familiaux et l'usage du tabac n'étaient pas prédictifs de l'apparition de la dyspepsie.

Conclusion: La prévalence de la dyspepsie est élevée chez les répondants de l'étude.

Mots clés: Dyspepsie, prévalence, université, Nigéria

\footnotetext{
*Auteur correspondant: DR Ogunmodede JA. Email: ayodeleogunmodede @yahoo.com

${ }^{1}$ Department of Medicine, Faculty of Clinical Sciences, University of Ilorin, Nigeria

${ }^{2}$ Department of Epidemiology and Community Health, Faculty of Clinical Sciences, University of Ilorin, Nigeria
} 


\section{INTRODUCTION}

Dyspepsia is a common gastrointestinal (GI) symptom which accounts for 3-4\% of all general practice consultation (1) and is the most common indication for upper GI endoscopy in several settings (2). Dyspepsia is a syndrome which is characterized by the presence of frequently occurring epigastric pain or discomfort that originates from the upper GI tract $(3,4)$ occurring alone or frequently accompanied by other upper GI symptoms such as heart burn, postprandial fullness, and early satiety (3) belching, vomiting, nausea, postprandial fullness, and early satiety $(5,6)$.

Dyspepsia is a common symptom which impacts significantly on quality of life, (79) increases healthcare expenditure and affects productivity due to reduced work periods and missed work days. $(10,11)$. The prevalence of dyspepsia varies widely among populations. It depends largely on population studied and the range of symptoms evaluated, diagnostic criteria used and symptom time frame.(12) Reported prevalence rates of uninvestigated dyspepsia range from $8.5 \%-56 \%(13,14)$. When the prevalence of functional dyspepsia alone is considered, the prevalence expectedly reduces to as low as $3 \%$ to $40 \%$ in selected hospital based studies $(15,16)$.

Most studies (15-18) on the prevalence and incidence of dyspepsia are hospital based, however dyspepsia as a symptom is often treated first using home remedies and over-the-counter medications (OTC's). Hence many dyspepsia complaints never reach a doctor. Hence what is seen in the health facility is probably just a tip of the iceberg (1) It therefore makes it important to assess the prevalence of the symptom in a setting that is close to the community in order to have a real feel of the impact of the symptom on public health. The study aimed at assessing the prevalence of self-reported dyspepsia symptoms and to determine its associated factors among administrative staff of the College of Health sciences of the University of Ilorin, Ilorin, North central Nigeria.

\section{MATERIALS AND METHODS}

The study was a cross-sectional study of the prevalence of symptoms of uninvestigated dyspepsia among administrative staff of the College of Health Sciences, University of Ilorin. The study was part of the 2014 student-centred Mini-project series of the Department of Medicine of the University of Ilorin carried out by the Gastroenterology unit of the department. A total of 53 staff were targeted through stratified random sampling of the faculties and units of the College. Every second staff member in every administrative cadre was selected and requested to complete a structured, intervieweradministered questionnaire after obtaining informed consent from them. The questionnaires were administered by two trained medical students who served as the interviewers. The questionnaire was pretested to determine its validity and applicability. The items in the questionnaire included age, sex, marital status, job description, anthropometric parameters, presence or absence of dyspepsia symptoms such as upper abdominal pain, heartburn, abdominal fullness/bloating, excessive belching, early satiety, nausea, vomiting, relationship of the abdominal pain to food, medications, day-night variability and the presence or absence of associated factors such as alcohol, tobacco, regular NSAID use, steroid use, calcium channel blockers, previous abdominal surgery and presence of family history of similar symptoms and of endoscopically-diagnosed acid peptic disorder (APD). The dependent variables were self-reported GI symptoms. Dyspepsia was defined as having upper abdominal pain, accompanied by (or without) other gastrointestinal symptom listed above lasting for at least 3 months and occurring at least one day per week.

Dyspepsia was further classified into four categories as adapted from previous studies. () Ulcer-like dyspepsia was defined as upper abdominal pain with at least two of the four symptoms: a) pain often relieved by food, b) pain often relieved by antacids or food, c) pain before meals or when hungry, d) night pain. Dysmotility-like dyspepsia referred to upper abdominal pain with at least three of the four symptoms; a) abdominal bloating and distension, b) pain often aggravated by food, c) pain often relieved by belching, d) early satiety. Reflux-like dyspepsia was considered present if there was heartburn or acid regurgitation, or both, while non-specific dyspepsia was upper abdominal pain or nausea that did not fit into the other categories.

\section{Statistical analysis}

The data obtained were analysed using the Statistical Package for Social Sciences (SPSS) version 16. Categorical variables were expressed as percentages while numerical values 
were presented as mean \pm standard deviation. Odds ratios and p-values were used to determine the significance of documented categorical risk factors associated with dyspepsia using two by two tables comparing respondents with and without dyspepsia. For risk factors that were continuous variables the means, standard deviations and $\mathrm{P}$ values were used. Categorical risk factors with their $\mathrm{p}$-values $<0.4$ were entered into a logistic regression model to identify the risk factors independently predictive of dyspepsia. A statistically significant association was taken at $P<0.05$.

\section{RESULTS}

Five people declined to participate in the study, leaving 48 participants. Twenty-eight $(58.3 \%)$ of the participants were female. The mean age of participants was $44.9 \pm 8.3$. The other anthropometric parameters and job specifications of the respondents are detailed in Table 1 . The prevalence of dyspeptic symptoms among the respondents was $37.5 \%$ and the most commonly reported symptom aside epigastric pain was bloating. Dyspepsia was commoner among female respondents though this did not reach statistical significance $(\mathrm{P}=0.36)$. Most dyspeptic individuals had at least 2 symptoms $(38.9 \%)$, while $2(11.2 \%)$ had 5 symptoms of dyspepsia. Dysmotility-like form of dyspepsia was commonest (77.8\%) (see Table 2). Though NSAID use [OR- 0.781, 95\% Confidence Interval (CI) $0.18-2.38, \mathrm{P}=0.74]$ was common among the respondents, it was not significantly associated with the occurrence of dyspepsia symptoms, likewise alcohol use and presence of DM (see Table 3). When factors with $\mathrm{P}$ values with $P$ value less than 0.4 such as sex and family history were entered together with age into a logistic regression model, only age was significantly predictive of the occurrence of dyspepsia among the subjects [OR-1.46, 95\% CI 1.042-2.045, $\mathrm{P}=0.03$ ] (see Table 4)

\section{DISCUSSION}

The worldwide pooled prevalence of uninvestigated dyspepsia was $20.8 \%$, (12) however local prevalence rates were reported to vary widely according to population studied and symptom range used $(16,19,21)$. Our study, though with a small sample size has the potential of depicting a situation closer to what exists in the community than what is offered by most studies which are largely hospital-based $(15,17,18)$. Though individuals with dyspepsia have similar life-expectancy as non-dyspeptic people, $(22,23)$ the significant impact on quality of life contributes to absenteeism, lower productivity at work, unused leisure periods and hence significant direct cost to the individual $(10,11)$ and probably greater indirect cost to the society as a whole than is ordinarily considered.

The prevalence of uninvestigated dyspepsia symptoms of $37.5 \%$ seen in this study is higher than that reported in an earlier randomized community-based study by Holcombe et al in North eastern Nigeria (24). It is however similar to $38.9 \%$ reported among health care workers of a large hospital in Rwanda (25). The Rwandan study is also a work-place based survey just like our study and reported findings across different strata of healthcare workers in a large referral hospital just as we did in a university setting. Similar findings of up to $40 \%$ have also been reported in the USA (16) Some of the prevalence rates reported from Asia are also comparable with our own, for example in West Iran (41.2\%), (19) though, patient selection and the number of symptoms studied have created a variation in reported prevalence rates from some societies. The commonest symptom our respondents had in addition to epigastric pain was the feeling of bloating (abdominal fullness). This made the dysmotility-like dyspepsia the commonest symptom cluster in our study. This is similar to observations by Shah et al in India (26) though different from observations in West Iran where subjects were found to have ulcer-like dyspepsia as the commonest sub-type (19). In our study however many of the subjects had an overlap of symptoms making the mixed group the second largest and underscoring the syndromic nature of dyspepsia.

Our study did not find the traditionally described association between dyspepsia and female sex, tobacco use and NSAID use. The small sample size and small number of individuals who smoked may have contributed to a perceived lack of association between tobacco use and dyspepsia in our study. However, Solomon et al in a much larger study also did not find any significant association of dyspepsia symptoms with NSAID, tobacco or alcohol use (27). This was a similar observation to that in even yet larger surveys in Rwandan and West Iran which reflected both hospital based and community-based methodology $(19,25)$. However, the association with NSAIDs and tobacco was described by other workers $(26,28)$. Though it is a risk factor for peptic ulcer disease, 
the impact of NSAID use on the development of dyspepsia may on its own be dependent on individual susceptibility and complement of other predisposing factors present. In our study, increasing age was significantly predictive of the occurrence of dyspepsia with an OR of 1.46 implying that every 1 year increase in age increased the chance of developing dyspepsia by 1.46 times. This observation is similar to that reported by Yadzapanah in a similar prevalence study in Iran (19) and Talley who reviewed an American cohort (29). Other associated factors reported in studies but not investigated in our own study include tea intake and eating of peppery food $(19,26,27,30)$, presence of depression (14) This suggests that the impact of local culture and diversity of food habits plays a considerable role on the occurrence of uninvestigated dyspepsia.

\section{CONCLUSION}

While our study may be limited by sample size, the importance of dyspepsia as a symptom and its impact on human productivityespecially in working-class individuals- and the influence of factors such as age can guide targeted screening and support even in the workplace. Further studies in our environment to investigate the role of other factors such as culture, geography as well as organic conditions will be necessary especially among subpopulations that are close to the community level such as ours in order to successfully paint an overall picture of the symptom worldwide.

Conflict of interest: The authors declare no conflict of interest

\section{REFERENCES}

1. Grainger SL, Klass HJ, M. O. Rake MO, Williams JG. Prevalence of dyspepsia: the epidemiology of overlapping symptoms. Postgrad Med J. 1994;70: 154-161.

2. Olokoba $A B$, Bojuwoye $B J$. Indications for oesophagogastroduodenoscopy in Ilorin, Nigeria - a 30 month review. Niger J Clin Pract 2010;13:260-263.

3. Al-Humayed SM, Mohammed-Elbagir AK, Al-Wabel AA, Argobi YA. The changing pattern of upper gastrointestinal lesions in Southern Saudi Arabia: An endoscopic study. Saudi J Gastroenterol2010;16:35-37.

4. Veldhuyzen van Zanten SJ, Flook N, Chiba N, Armstrong D, Barkin A, et al. An evidencebased approach to the management of patients with dyspepsia in the era of Helicobacter pylori. Can Med Assoc J 2000;162:S3-23.

5. El-Serag HB, Talley NJ. Systemic review: the prevalence and clinical course of functional dyspepsia. Aliment Pharmacol Ther 2004; 19:643-54.

6. Ofman JJ, Maclean CH, Straus WL, Morten SC, Berger ML, Roth EA, et al. Meta-analysis of dyspepsia and nonsteroidal antiinflammatory drugs. Arthritis Rheum 2003; 49: 508-18.

7. Mones J, Adan A, Segu JL, López JS, Artés M, Guerrero T. Quality of life in functional dyspepsia. Dig Dis Sci 2002;47:20-6.

8. Halder SL, Locke GR, Talley NJ, Fett SL, Zinsmeister AR, Melton LJ 3rd. Impact of functional gastrointestinal disorders on healthrelated quality of life: A population-based case-control study. Aliment Pharmacol Ther 2004; 19:233-42.

9. Enck P, Dubois D, Marquis P. Quality of life in patients with upper gastrointestinal symptoms: Results from the domestic / international gastroenterology surveillancestudy (DIGEST). Scand J Gastroenterol 1999;34:4854.

10. Camilleri M, Dubois D, Coulie B, Jones M, Kahrilas PJ, Rentz AM, et al. Prevalence and socioeconomic impact of upper gastrointestinal disorders in the United States: Results of the US Upper Gastrointestinal Study. Clin Gastroenterol Hepatol 2005;3:54352.

11. Brook RA, Kleinman NL, Choung RS, Melkonian AK, Smeeding JE, Talley NJ, et al. Functional dyspepsia impacts absenteeism and direct and indirect costs. Clin Gastroenterol Hepatol 2010;8:498-503.

12. Ford AC, Marwaha A, Sood R, Moayyedi P. Global prevalence of and risk factors for uninvestigated dyspepsia: a meta-analysis. Gut 2015;64:1049-57

13. Wallander MA, Johansson S, Ruigomez A, Garcia Rodriguez LA, Jones R. Dyspepsia in general practice: incidence, risk factors, comorbidity and mortality. Fam Pract 2007; 24: 403-11.

14. Barzkar M, Pourhoseingholi MA, Habibi M, Moghimi-Dehkordi B, Safaee A, Pourhoseingholi A, et al. Uninvestigated dyspepsia and its related factors in an Iranian community. Saudi Med J 2009; 30: 397-402.

15. Olokoba AB, Salawu FK, Vickola JA. Functional dyspepsia in Nigeria. Res J Health Sci 2015;3:38-44.

16. Shaib Y, El-Serag HB. The prevalence and risk factors of functional dyspepsia in a multiethnic population in the United States. Am J Gastroenterol 2004; 99:2210-6.

17. Ford AC, Forman D, Bailey AG, Axon ATR, Moayeddi P. Effect of dyspepsia on survival: A longitudinal 10-year follow-up study. Am J Gastroenterol 2012;107:912-21.

18. Wahass S, Khalil MS, Al Qurain AA, Yasawy 
MI. The impact of functional dyspepsia on health-related quality of life in Saudi patients. The Saudi Journal of Gasrroenterology 2006;12(3):126-9.

19. Yazdanpanah K, Moghimi N, Yousefinejad V, Ghaderi E, Azizi A, Nazem SF. Dyspepsia prevalence in general population aged over 20 in the west part of Iran. JPMA 2012;62: 672-6.

20. Masoumi SJ, Mehrabani D, Moradi F, Zare N, Saberi-Firouzi M, Mazloom Z. The prevalence of dyspepsia symptoms and its correlation with the quality of life among Qashqai Turkish migrating nomads in Fars Province, Southern Iran. Pak J Med Sci 2015;31:325-30.

21. Kim SE, Park HK, Kim N, Joo YE, Baik GH, Shin JE, et al. Prevalence and risk factors of functional dyspepsia: a nationwide multicenter prospective study in Korea. J Clin Gastroenterol 2014;48:e12-8.

22. Ford AC, Forman D, Bailey AG, Axon ATR, Moayeddi P. Effect of dyspepsia on survival: A longitudinal 10-year follow-up study. Am J Gastroenterol 2012;107:912-21.

23. Chang JY, Locke III GR, McNally MA et al. Impact of functional gastrointestinal disorders on survival in the community. Am J Gastroenterol 2010;105:822-32.

24. Holcombe C, Omotara BA, Padone MKO, Bassi AP. The prevalence of symptoms of dyspepsia in North-Eastern Nigeria: A random community-based survey. Tropical and geographical medicine 1991;43:209-14.

25. Bitwayiki R , Orikiiriza JT, Kateera F, Bihizimana P, Karenzi B, Kyamanywa P, et al. Dyspepsia prevalence and impact on quality of life among Rwandan healthcare workers: A cross-sectional survey. S Afr Med J 2015;105:1064-9.

26. Shah SS, Bhatia SJ, Mistry FP. Epidemiology of dyspepsia in the general population in Mumbai. Indian J Gastroenterol 2001;20:1036.

27. Solomon OA, Ajayi AO. Risk factors for uninvestigated dyspepsia among primary care patients in northern Nigeria. African Health Sciences 2013;13: 1007-11.

28. Khademolhosseini F, Mehrabani D, Zare N, Salehi M, Heydari ST, Beheshti M, SaberiFiroozi M. Prevalence of Dyspepsia and its Correlation with Demographic Factors and Lifestyle in Shiraz, Southern Iran. Middle East J Dig Dis. 2010;2:24-30.

29. Talley NJ, Weaver AL, Zinsmeister AR. Smoking, alcohol, and nonsteroidal antiinflammatory drugs in outpatients with functional dyspepsia and among dyspepsia subgroups. Am J Gastroenterol 1994; 89: 5248.

30. Mahadeva S, Goh KL. Epidemiology of functional dyspepsia: a global perspective. World J Gastroenterol 2006; 12:2661-6. 
Table 1: Characteristics of the study subjects

\begin{tabular}{lll}
\hline Characteristics & $\begin{array}{l}\text { Number } \\
(\mathrm{N}=48)\end{array}$ & Percentage (\%) \\
\hline Sex & 20 & 41.7 \\
$\quad$ Male & 28 & 58.3 \\
Female & & \\
& $44.9 \pm 8.3$ & \\
Age, yrs (mean $\pm \mathrm{SD})$ & & \\
& & 35.4 \\
Job description & 17 & 29.2 \\
$\quad$ Secretary & 14 & 2.1 \\
Office assistant & 1 & 2.1 \\
$\quad$ Accountant & 1 & 2.1 \\
$\quad$ Legal practitioner & 1 & 29.2 \\
$\quad$ IT Specialist & 14 & \\
Administrator &
\end{tabular}

*BMI- Body Mass Index

Table 2: Distribution of dyspepsia symptoms among the study subjects

\begin{tabular}{|c|c|c|}
\hline Variables & Number & Percentage \\
\hline \multicolumn{3}{|l|}{ Dyspepsia Present } \\
\hline Yes & 18 & 37.5 \\
\hline Male & 6 & 30 \\
\hline Female & 12 & 42.9 \\
\hline No & 30 & 62.5 \\
\hline \multicolumn{3}{|l|}{ Symptoms } \\
\hline Epigastric pain & 18 & 37.5 \\
\hline Heart burn & 9 & 18.8 \\
\hline Bloating & 10 & 20.8 \\
\hline Excessive belching & 2 & 4.2 \\
\hline Anorexia & 6 & 12.5 \\
\hline Nausea & 4 & 8.3 \\
\hline \multicolumn{3}{|l|}{$\begin{array}{c}\text { Associated Factors } \\
\text { NSAIDS }\end{array}$} \\
\hline Yes & 39 & 81.2 \\
\hline No & 9 & 18.8 \\
\hline \multicolumn{3}{|l|}{ Tobacco use } \\
\hline Yes & 1 & 2.1 \\
\hline No & 47 & 97.9 \\
\hline \multicolumn{3}{|l|}{ Alcohol use } \\
\hline Yes & 4 & 8.3 \\
\hline No & 44 & 91.7 \\
\hline \multicolumn{3}{|l|}{ Family history } \\
\hline Yes & 11 & 22.9 \\
\hline No & 37 & 77.1 \\
\hline \multicolumn{3}{|l|}{ Diabetes Mellitus } \\
\hline Yes & & 4.2 \\
\hline No & $\begin{array}{l}2 \\
46 \\
\end{array}$ & 95.8 \\
\hline
\end{tabular}


Table 3: characteristics of subjects with dyspepsia

\begin{tabular}{llll}
\hline Characteristic & $\begin{array}{l}\text { Number } \\
(\mathrm{N}=18)\end{array}$ & Percentage & P value \\
\hline Sex & 6 & 33.3 & 0.36 \\
$\quad$ Male & 12 & 66.7 & \\
Female & & & \\
& & 61.1 & \\
Type of Dyspepsia & 11 & 38.9 & \\
$\quad$ Mixed & 7 & 44.4 & \\
$\quad$ Ulcer-like & 8 & 77.8 & \\
Reflux-like & 14 & 38.9 & \\
Dysmotility-like & 7 & & \\
Non-specific & & 38.9 & \\
& & 22.2 & \\
Number of Symptoms & 7 & 27.8 & \\
2 & 4 & 11.2 & \\
3 & 5 & & \\
4 & 2 & & \\
5 & &
\end{tabular}

Table 4: Associated factors of uninvestigated dyspepsia

\begin{tabular}{lll}
\hline FACTOR & OR (Confidence Interval) & P value \\
\hline Sex & $0.57(0.17-1.93)$ & 0.36 \\
Family history & $3.65(0.89-14.9)$ & 0.06 \\
Diabetes mellitus & $1.56(0.91-26.5)$ & 0.76 \\
Alcohol use & $1.59(0.20-12.36)$ & 0.66 \\
NSAID use & $0.7(0.16-3.04)$ & 0.63 \\
\hline
\end{tabular}

Table 5: Logistics regression of factors associated with uninvestigated dyspepsia

\begin{tabular}{lllll}
\hline FACTOR & $\begin{array}{l}\text { OR (95\% Confidence } \\
\text { Interval) }\end{array}$ & Coefficient & Standard Error & P value \\
\hline Age & $1.46(1.042-2.045)$ & 4.832 & 0.172 & $0.03^{*}$ \\
Sex & $3.65(0.89-14.9)$ & 0.62 & 0.52 & 0.43 \\
Family history & $1.56(0.91-26.5)$ & 0.07 & 18.2 & 0.79 \\
\hline
\end{tabular}

* Statistically significant relationship 